\title{
MICROEARTHQUAKE ACTIVITY ADJACENT TO THE ROCKLIN PLUTON NEAR AUBURN, CALIFORNIA
}

\author{
By K. C. MeNally, G. W. Simila, and F. J. Von Dollen
}

The occurrence of the Oroville earthquake $\left(M_{L}=5.7\right)$ of August 1,1975 heightened interest in the seismotectonics of the Sierra foothills region and particularly the Foothills fault system. Clark (1960) recognized the Foothills fault system as heing a major structural feature of the western Sierra Nevada. An 11-week reconnalssance microearthquake study was conducted by Woodward-Clyde Consultants (WCC) for the U.S. Bureau of Reclamation (USBR) to assess the seismic activity of the Sierra foothills $75 \mathrm{~km}$ S-SE of Oroville near Auburn, California. Microearthquake activity was detected in the Rocklin-Auburn region with eight events recorded during July 1 to July 24 and seven events during August 15 to October 8, 1976 (see Figure 1). The mobile seismic array consisted of eight Sprengnether MEQ-800 portable seismographs with Mark Products L-4C vertical seismometers. Data recordings were normally 48 hours in length, with a record speed of $1 \mathrm{~mm} / \mathrm{sec}$.

The microearthquake hypocenters were determined by the computer program HYPOELLIPSE (Lahr and Ward, 1977). A $P$-wave velocity of $5.9 \mathrm{~km} / \mathrm{sec}$ for a layer with $12 \mathrm{~km}$ thickness over a half-space with a $P$ velocity of $6.7 \mathrm{~km} / \mathrm{sec}$ was used. This crustal-velocity model is consistent with recent seismic refraction data for upper crustal depths near Oroville (Spieth and Hill, 1977). Both $P$ - and $S$-wave arrivals were used in the solutions. Accuracy of the hypocentral parameters is estimated to be approximately $\pm 2 \mathrm{~km}$. Based on preliminary WCC reports of seismic activity near Rocklin, the California Division of Mines and Geology (CDMG) installed five microearthquake recorders in the area north of Rocklin beginning August 11, 1976 (Cramer and Sherburne, 1977). Data recorded by stations in the Auburn Dam array, operated by the U.S. Geological Survey (USGS) for USBR, were used to improve locations of the July 1 to July 24 events near Rocklin. The seven events detected from August 15 to October 8 were located in the vicinity of Rocklin with combined data from the USGS, CDMG, and WCC arrays. Special attention was given to the blasting associated with construction in the Auburn-Rocklin area, and the data from blasting reports (Bureau of Reclamation and local quarries) are not included in the listing. The magnitudes of the recorded events (Table 1 ) were estimated from a modified coda lengthmagnitude relationship, $M_{L}=-2.72+2.98 \log T$, where $T$ is the $F-P$ earthquake duration time (Lee et al., 1972) in seconds measured on the MEQ-800 seismograms. This relationship was determined from a correlation with U. C. Berkeley magnitudes for earthquakes recorded at Oroville $\left(1.0 \leqq M_{L} \leqq 4.1\right)$, but should be considered approximate. The magnitude range determined for the "microearthquakes was approximately 0.0 to 1.1 .

All microearthquakes located by the present study in the Rocklin, California region are shown in Figure 1 and listed in Table 1 . Of the 15 events, 13 were located within an area 2 to $7 \mathrm{~km} \mathrm{E-NE} \mathrm{of} \mathrm{Rocklin.} \mathrm{The} \mathrm{additional} \mathrm{two} \mathrm{events} \mathrm{indicated} \mathrm{activity} \mathrm{in}$ the northern region of the Rocklin pluton. An additional four events with $M_{L}<0.0$ were reported by Cramer and Sherburne (1977) indicating activity at $121^{\circ} 11^{\prime} \mathrm{W}$ from $38^{\circ} 54^{\prime}$ to $38^{\circ} 55^{\prime} \mathrm{N}$. The locality of the recorded microearthquake activity is one of historically low seismicity. Three felt events have been reported with maximum intensities of II to III (Modified Mercalli) that occurred on February 22, 1885, April 


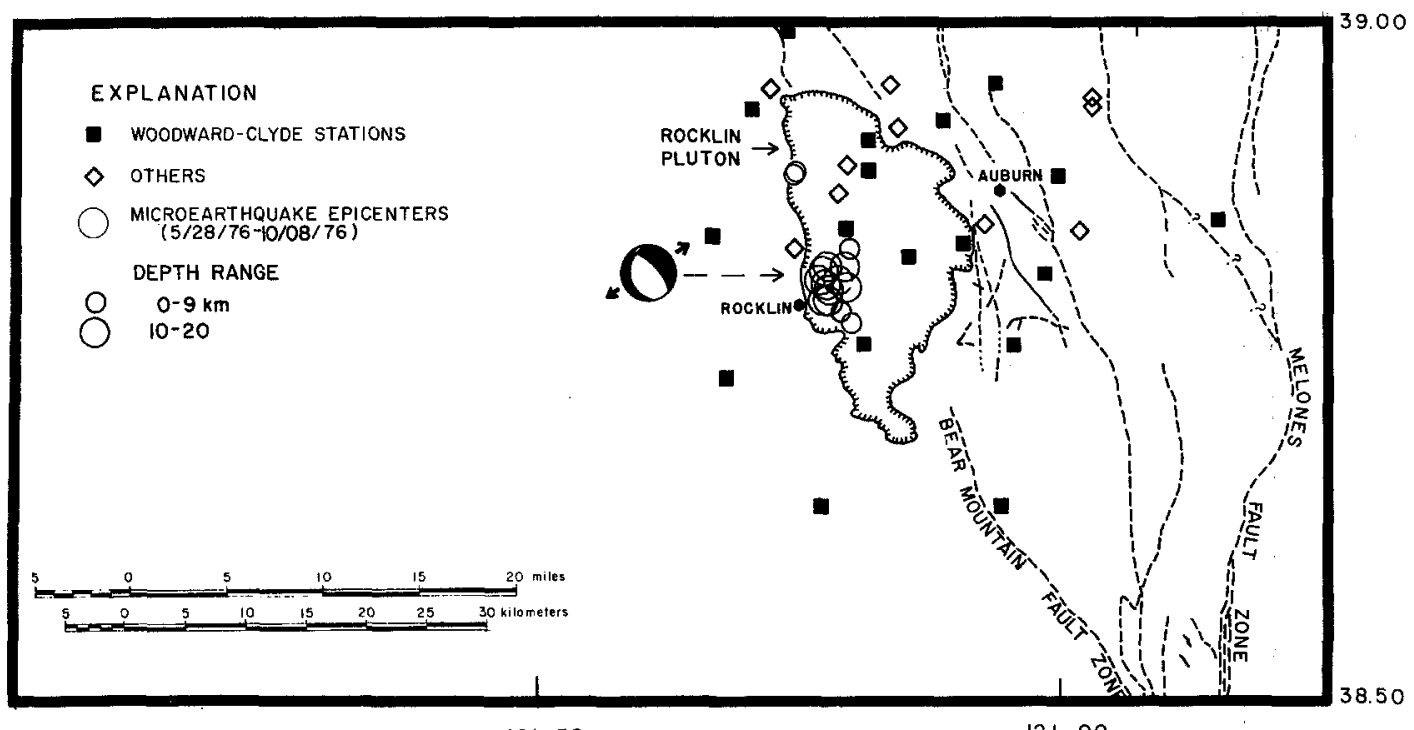

121.50

121.00

FIG. 1. Hypocenters of microearthquakes recorded near Rocklin, California. Focal mechanism from Figure 2. Dark quadrant denotes compression. Arrows indicate direction of principal tensional stress. Faults and geology from Geologic'Map of California, Sacramento Sheet (Strand and Koenig, 1965).

TABLE 1

Microearthquakes Recorded in the Vicinity of Rocklin

\begin{tabular}{|c|c|c|c|c|c|c|c|}
\hline Year & Month & Day & Origin (GMT) & Lat $\left({ }^{\circ} \mathrm{N}\right)$ & Long $\left({ }^{\circ} \mathrm{W}\right)$ & Depth $(\mathrm{km})$ & Magt \\
\hline \multirow[t]{8}{*}{1976} & July & 05 & 1043:04.3 & $3846.8^{\prime}$ & $12112.3^{\prime}$ & 05.7 & 0.0 \\
\hline & $*$ & 12 & $1820: 11.0$ & $3849.3^{\prime}$ & $12112.7^{\prime}$ & 13.1 & 1.1 \\
\hline & $*$ & 13 & 0436:09.6 & $3848.7^{\prime}$ & $12113.1^{\prime}$ & 15.5 & 0.2 \\
\hline & $*$ & & $0907: 07.3$ & $3849.1^{\prime}$ & $12113.9^{\prime}$ & 12.6 & 0.2 \\
\hline & & & $1513: 03.6$ & $3850.1^{\prime}$ & $12112.4^{\prime}$ & 02.9 & 0.4 \\
\hline & & & $2215: 52.4$ & $3853.4^{\prime}$ & $12115.9^{\prime}$ & 00.2 & 0.4 \\
\hline & & 16 & $1907: 32.9$ & $3853.5^{\prime}$ & $12115.5^{\prime}$ & 05.5 & 0.2 \\
\hline & $*$ & 19 & $1453: 54.0$ & $3848.4^{\prime}$ & $12112.6^{\prime}$ & 14.2 & 0.4 \\
\hline \multirow[t]{4}{*}{1976} & Aug. & 19 & $1301: 32.4$ & $3848.7^{\prime}$ & $12114.5^{\prime}$ & 14.2 & 0.0 \\
\hline & $*$ & 26 & $2230: 53.2$ & $3848.7^{\prime}$ & $12114.2^{\prime}$ & 12.6 & 0.4 \\
\hline & $*$ & 27 & $0037: 31.6$ & $3847.8^{\prime}$ & $12113.7^{\prime}$ & 14.1 & 1.0 \\
\hline & $*$ & & $1230: 03.9$ & $3847.8^{\prime}$ & $12113.9^{\prime}$ & 13.6 & 0.0 \\
\hline \multirow[t]{3}{*}{1976} & Sept. & 07 & $2114: 06.9$ & $3848.5^{\prime}$ & $12113.8^{\prime}$ & 14.5 & 0.4 \\
\hline & $*$ & 10 & $0709: 18.1$ & $3849.3^{\prime}$ & $12113.7^{\prime}$ & 14.6 & 0.0 \\
\hline & & 21 & $1803: 53.8$ & $3847.3^{\prime}$ & $12112.9^{\prime}$ & 04.1 & 0.0 \\
\hline
\end{tabular}

* Events used in fault-plane solution.

$\dagger$ Determined from modified coda length-magnitude relationship.

21, 1892, and May 30, 1908 (Townley and Allen, 1939). No more recent events have been noted for this locality (Bolt and Miller, 1975).

A group of 10 events located northeast of Rocklin (Figure 1) occurred at depths of 12 to $15 \mathrm{~km}$. A composite fault-plane solution (CFPS) was determined for these events and is shown in Figure 2. The first-motion data from the $P$-wave arrivals are presented on an equal area, lower hemisphere projection. The CFPS is a superposition of projections onto the focal sphere of the $P$-wave polarities for all earthquakes in the composite group. Our CFPS method used the technique by McEvilly (1966) 
which assumes a velocity model with a linear velocity gradient in a layer over a halfspace. The velocity-depth model used was $V=5.6+0.08 \mathrm{Z}$ where $V=$ velocity $(\mathrm{km} / \mathrm{sec})$ and $Z=\operatorname{depth}(\mathrm{km})$. This model approximates the velocity model discussed earlier. Determination of the nodal planes is constrained primarily by the compressional first motions in the southwest quadrant. This nodal plane strikes $\mathrm{N0} 2^{\circ} \mathrm{W}$ with westward dip of $30^{\circ}$. The strike of the auxiliary plane is more poorly constrained. The variation in strike is $\mathrm{N} 10^{\circ} \mathrm{W}$ to $\mathrm{N} 42^{\circ} \mathrm{W}$ with eastward dip of $60^{\circ}$ to $70^{\circ}$. Interpretation of the composite focal mechanism suggests normal faulting representing E-W

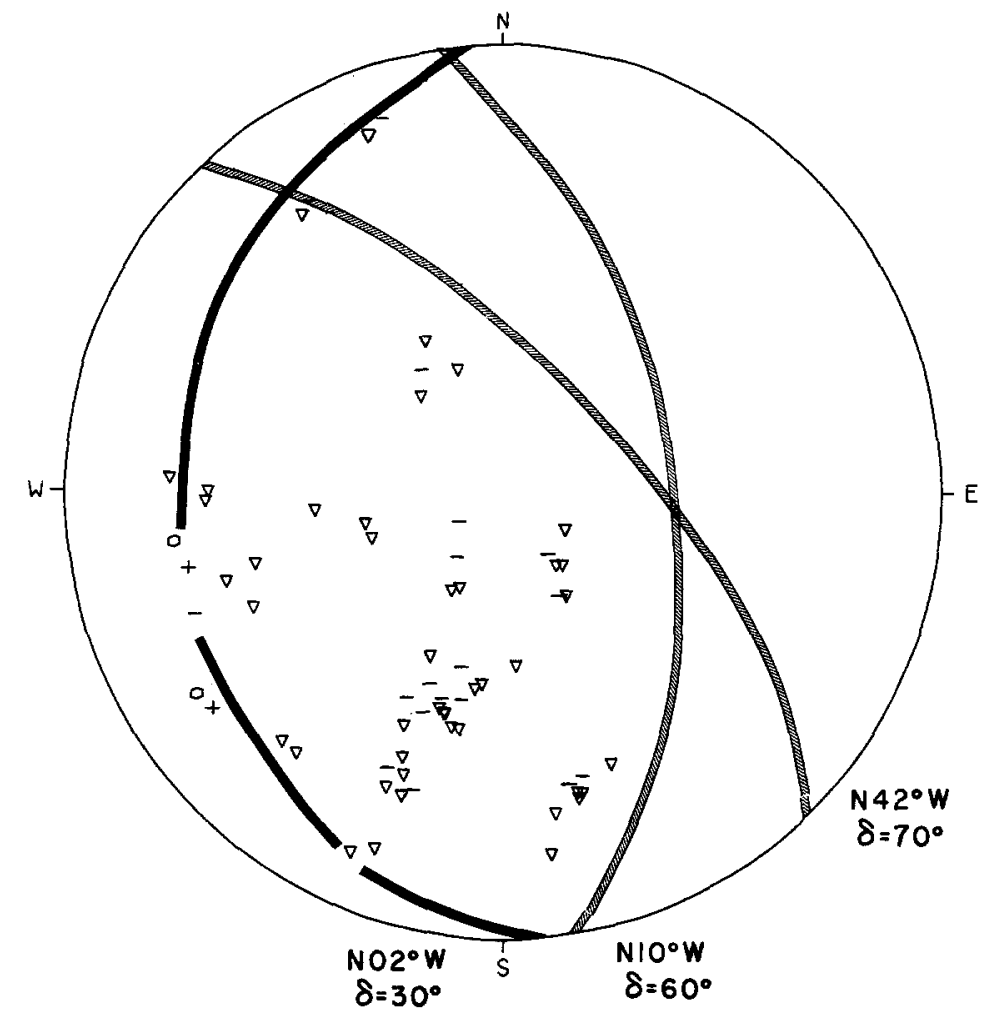

FIG. 2. Composite fault-plane solution from nine events (Table 1) near Rocklin, California. Circles are compressions; triangles, dilatations. Questionable readings are compression $(+)$; dilatations $(-)$. Lower hemisphere equal-area projections of first motion data. Variation in nodal plane indicated by striped lines.

principal extensional stresses. This is similar to the $\mathrm{E}-\mathrm{W}$ extension occurring in the Great Valley near Oroville (Lester et al., 1975).

Possible models for association of the observed microearthquakes with surface geological features are based on the geometric projection of the alternate fault planes to the surface from the hypocentral depth of 12 to $15 \mathrm{~km}$. If the plane striking $N 02^{\circ} \mathrm{W}$ with westward dip of $30^{\circ}$ is selected as the fault plane, the projection to the surface is at 21 to $26 \mathrm{~km}$ east of the epicenters (shown in Figure 1) and $9 \mathrm{~km}$ southeast to $13 \mathrm{~km}$ east-southeast of the town of Auburn. Mapped surface traces of the Foothills fault system are found at both distances with strike consistent with $\mathrm{N} 02^{\circ} \mathrm{W}$. This interpretation seems somewhat unlikely, however, as it requires that a plane of lowangle faulting associated with the fault system cut the Rocklin pluton by which it was intruded. The age of the Rocklin pluton has been determined radiometrically 
to be 125 m.y. by Evernden and Kistler (1970)and 130 to 131 m.y. by Curtis et al. (1958), with intrusions occurring during the Yosemite epoch (130 to $150 \mathrm{~m} . \mathrm{y}$. ) of the Sierra Nevada batholith (Kistler et al., 1971). It has been suggested by Olmstead (1971) that the shear zone is Jurassic and the intrusion of the pluton truncated the Bear Mountains strand of the Foothills fault system. Generally, the faults in this region are steeply dipping (Olmsted, 1971; Clark, 1960).

Alternatively, if the plane striking $\mathrm{N} 10^{\circ} \mathrm{W}$ to $\mathrm{N} 42^{\circ} \mathrm{W}$ with eastward dip of $60^{\circ}$ to $70^{\circ}$ is selected as the fault plane, the projection to the surface is between 7 to $8 \frac{1}{2} \mathrm{~km}$ west and $4 \frac{1}{2}$ to $5 \frac{1}{2} \mathrm{~km}$ southwest of the epicenters shown in Figure 1. This places the surface expression of faulting at the western edge of the Rocklin pluton as mapped at the surface and does not require that the fault plane cut the pluton. Two models for intrusion related earthquakes have been proposed by Long (1976) and McKeown (1975), and Campbell (1977), which invoke rigidity contrasts between the intrusions and surrounding crustal rocks. According to these models, existing regional stresses might be amplified or focused within or at boundaries of plutons. Recent leveling data reported by Bennett et al. (1977) have suggested possible minor crustal movements in the Rocklin pluton-Foothills shear zone region. The north-northwest to northwest strike of the fault-plane solution nodal planes is not inconsistent with the trend of the mapped surface trace of the Bear Mountains fault zone (Figure 1).

In summary, the more reasonable model is of normal faulting on a plane striking north-northwest to northwest, and dipping to the east at $60^{\circ}$ to $70^{\circ}$. This is similar to the east-west extension found in Oroville, but different in that the downdropped block at Oroville is to the west.

\section{ACKNOWLEDGMENTS}

We gratefully thank the U.S. Bureau of Reclamation for support in conducting this study, and the U.S. Geological Survey and the California Division of Mines and Geology for generously sharing data. We sincerely thank P. Corbett, B. Foxall, F. Arioli, and B. Todd for field work; B. Munden and V. Chernock for preliminary data processing; and R. Thompson for technical instrumentation assistance. Woody Savage, Tom Turcotte, and Don Tocher provided helpful comments and suggestions.

\section{REFERENCES}

Bennett, J. H., G. C. Taylor, and T. R. Toppozada (1977). Crustal movement in the northern Sierra Nevada, Calif. Geology 30, 51-57.

Bolt, B. A. and R. D. Miller (1975). Catalogue of earthquakes in northern California and adjoining areas, 1 January 1910-31. December 1972, Seismographic Stations, Univ. of California, Berkeley, California, 1-567.

Campbell, D. L. (1977). Implications of Kanes's stress-concentration mechanism for intraplate earthquakes, (abstract), Trans. Am. Geophys. Union 58, 431.

Clark, L. D. (1960). Foothills fault system, western Sierra Nevada, California, Bull. Geol. Soc. Amer. 71, 483-496.

Cramer, C. H. and R. W. Sherburne (1977). Microearthquake activity in the Rocklin-Penryn pluton west of Auburn, California, Geol. Soc. Am. (abstracts with programs) 9, 405-406.

Curtis, G. H., J. F. Evernden, and J. Lipson (1958). Age determination of some granitic rocks in California by potassium-argon method, Calif. Div. Mines Spec. Rept. 54, 16 pp.

Evernden, J. F. and R. W. Kistler (1970). Chronology of emplacement of Mesozoic batholithic complexes in California and western Nevada, Geol. Surv. Prof. Paper 623, 1-28.

Kistler, R. W., J. F. Evernden, and H. R. Shaw (1971). Sierra Nevada plutonic cycle: part 1, origin of composite granitic batholiths, Bull. Geol. Soc. Am. 82, 853-868.

Lahr, J. C. and P. Ward (1977). HYPOELLIPSE: A computer program for determining local earthquake hypocentral parameters, magnitude, and first motion pattern: U. S. Geological Survey Open File Report (in preparation). 
Lee, W. H. K., R. E. Bennett, and K. L. Meagher (1972). A method of estimating magnitude of local earthquakes from signal duration, U. S. Geological Survey Open-File Report, $28 \mathrm{pp}$.

Lester, F. W., L. G. Bufe, K. M. Lahr, and S. W. Steward (1975). Aftershocks of the Oroville earthquake of August 1, 1975; California Division of Mines and Geology Special Report 124, 131-138.

Long, L. T. (1976). Speculations concerning southeastern earthquakes, mafic intrusions, gravity anomalies, and stress amplification, Earthquake Notes 47, 29-35.

McEvilly, T. V. (1966). The earthquake sequence of November 1964 near Corralitos, California, Bull. Seism. Soc. Am. 56, 755-773.

McKeown, F. A. (1975). Hypothesis: Mafic intrusives and their contact zones are source zones of many earthquakes in central and southeastern United States, Earthquake Notes 46, 53.

Olmsted, F. H. (1971). Pre-Cenozoic geology of the south half of the Auburn 15-minute quadrangle, Calif. Geol. Surv. Bull. 1341, 1-29.

Spieth, M. A. and D. P. Hill (1977). Crustal structure in the vicinity of Oroville, California from seismic refraction data, Geol. Soc. Am. (abstracts with programs) 9, 506.

Strand, R. G. and J. B. Koenig (1965). Geologic map of California, Olaf P. Jenkins edition, Sacramento sheet: California Division of Mines and Geology, scale 1:250,000.

Townley, S. D. and M. W. Allen (1939). Descriptive catalog of earthquakes of the Pacific Coast of the United States 1769-1928, Bull. Seism. Soc. Am. 29, 1-297.

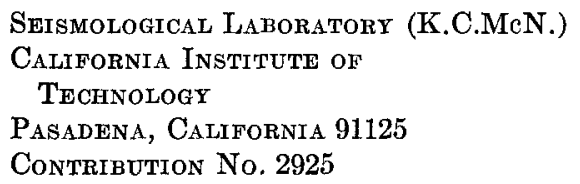

Contribution No. 2925

Seismographic Station (G.W.S.)

Department of Geology and

GEOPHYSICS

UNIVERSITY OF CALIFORNIA

Berkeley, CaLrfornia 94720

Woodward-Chyde Consultants (F.J.V.D.)

Three Embarcadero Center

SUITE 700

San Francisco, California 94111

Manuscript received May 11, 1977 